\title{
INTERNATIONAL COORDINATION OF A FIRST-YEAR COURSE ON SUSTAINABILITY IN ENGINEERING DESIGN
}

\author{
Amy C. Hsiao \\ Faculty of Sustainable Design Engineering, University of Prince Edward Island \\ ahsiao@upei.ca \\ Rasha Elshafei \\ Faculty of Sustainable Design Engineering, University of Prince Edward Island \\ Rasha.ElShafei@upei.ca
}

\begin{abstract}
A$ growing trend in the recruitment of undergraduate students to engineering programs at Canadian universities is to establish an international presence at a branch campus in a different part of the world. This paper focuses on an example case study of the international collaboration of an introductory engineering course called "Sustainability in Engineering Design" between the University of Prince Edward Island (UPEI) and the Universities of Canada (UofCanada-Cairo) in Cairo, Egypt. This course set out as being foundational in the implementation of an identical, international offering of the UPEI Faculty of Sustainable Design Engineering's (FSDE) Bachelor of Science in Sustainable Design Engineering (BSC-SDE) program at the Cairo campus. This paper describes the implementation of the course at the branch (UofCanada-Cairo) campus and the coauthors, as instructors, provide a self-assessment of the success of the coordination to deliver the learning outcomes for the course. An assessment of how well the main graduate attributes (i.e. GA9: Impact on Society and Environment; GA6: Individual and Team Work, and GA13: Lifelong Learning) linked to the course's learning outcomes were achieved in developing a sustainability mindset in UPEI FSDE undergraduate students will be presented and recommendations for the course in the context of international collaboration will be discussed. The projects' assessment also affirms that students at both campuses can work in teams to evaluate the impact of current engineering designs on society and environment and design more sustainable products in the future.
\end{abstract}

Keywords: sustainability mindset in engineering design, impact on society, environment stewardship professionalism and teamwork.

\section{INTRODUCTION}

Having an international branch campus (IBC) has accounted for most of the growth in transnational higher education. Learners are in a country different from the one where the degree-awarding institution is based [8]. The motivation for establishing an international branch campus stems mainly from the host institution's desire to grow "beyond" itself by creating a competitive edge for recruitment, and in doing so, the host institution also aims to establish or strengthen its international presence [3].

According to the latest report released by The CrossBorder Education Research Team in 2020 [2], the largest host countries for international branch campuses are the United Arab Emirates and China. At the same time, the largest source countries are the United States, Australia, and the United Kingdom. Even though Canada has a limited number of IBCs, one of the first Canadian branch campuses in Egypt that opened its doors in September 2018 is the UPEI Cairo campus hosted by UofCanada-Cairo.

This paper focuses on the collaboration between both campuses for the course "Sustainability in Engineering Design," which introduces sustainability principles in engineering design as they relate to the interactions among humans, living systems, the natural environment, and the engineered world. Physical, chemical, biological, ecological, social, economic, and life-cycle concepts, and their relevance to sustainable engineering design are introduced. The international coordination of this course is interesting as well for its pedagogical motivation, as engineering considers many aspects of sustainability which reflect the culture and the contextual environment [7]. For example, students in the course are introduced to how professional ethics, environmental stewardship, and matters of health and safety are perceived and applied in two different contexts: Canada and Egypt.

\section{INTERNATIONAL COLLABORATION}

\subsection{Program Planning and Synergy}

The international collaboration began in July 2017 when the FSDE instructor, along with the FSDE dean and the director of industry partnership, made their initial visit to the UofCanada-Cairo campus. Since then, there have been at least two visits every year to UofCanada-Cairo by the dean and the director of industry partnerships in the 
FSDE. The formal agreement to offer delivery of the accredited Bachelor of Science in Sustainable Design Engineering at this international branch campus was established 2018. In September of 2019, the UofCanadaCairo instructor was invited to visit the UPEI campus for a period of seven (7) days. The UPEI instructor created the itinerary for Cairo instructor and served as the host of her visit. The visit included the Cairo instructor giving a guest lecture in the course ENGN 1410 "Sustainability in Engineering Design" to Year 1 students, observation of teaching during ENGN 1410 lectures, tours of FSDE building and the senior engineering design project bays with the FSDE Manager of Operations, observation of junior students during design build days, an extended meeting with the Director of Student Experience to discuss future CEAB-accreditation requirements, meetings with the Dean, and a research seminar to have the Cairo instructor qualify for the criteria to be given adjunct faculty status at UPEI. The two instructors spent most of the afternoons in Dr. Hsiao's lab learning from each other and practicing the projects that were going to be offered concurrently. The Cairo instructor also had "free time" in the evenings and on the weekends and was able to experience Charlottetown's Farm Day in the City, for which she integrated into her guest lecture later that week and in her future classes.

\subsection{Course Structure and Sustainability Topics}

Tables 1 and 2 show the evaluation criteria for the course at both campuses. The percentage distribution is similar. Table 3 lists the Learning Outcomes, which were set by the UPEI instructor and followed in the Cairo offering of the course.

The content of the course was divided into two sections, developing the engineering student as a global citizen to understand the various facets of Sustainability, and developing the student as a future engineer to understand the specific technical, social/demographic, environmental, legal/regulatory and economic issues. Table 4 shows the course content over a 14-week semester.

Table 1: Evaluation Criteria for ENGN 1410-UPEI.

\begin{tabular}{|l|r|}
\hline & $\begin{array}{l}\text { \% of Final } \\
\text { Mark }\end{array}$ \\
\hline Weekly Check-Ins (Individual) & 10 \\
\hline Midterm (Individual) & 16 \\
\hline $\begin{array}{l}\text { Two Assignments: Living Lab on } \\
\text { Plastic Waste and Materials Life Cycle } \\
\text { Analysis (Team) }\end{array}$ & 16 \\
\hline $\begin{array}{l}\text { Two Lab Memos: Sustainable Soap } \\
\text { and Solar Cells (Team) }\end{array}$ & 16 \\
\hline Final Examination (Individual) & 28 \\
\hline $\begin{array}{l}\text { Leadership in Sustainability Project } \\
\text { (Team) }\end{array}$ & 10 \\
\hline Professionalism and Engagement & 4 \\
\hline Total & $\mathbf{1 0 0}$ \\
\hline
\end{tabular}

Table 2: Evaluation Criteria for ENGN 1410-UofCanadaCairo.

\begin{tabular}{|l|c|}
\hline & \multicolumn{2}{|c|}{$\begin{array}{l}\text { Mof Final } \\
\text { Mark }\end{array}$} \\
\hline $\begin{array}{l}\text { Weekly Check-Ins, Moodle } \\
\text { Quiz (Individual) }\end{array}$ & 10 \\
\hline Mid-Term (Individual) & 15 \\
\hline Assignment 1 + Presentation & 15 \\
\hline Assignment 2 + Presentation & 15 \\
\hline Final Exam (Individual) & 25 \\
\hline Professionalism and Engagement & 5 \\
\hline $\begin{array}{l}\text { Living lab/ On-campus Lab + } \\
\text { Presentation }\end{array}$ & 15 \\
\hline Total & $\mathbf{1 0 0}$ \\
\hline
\end{tabular}

Table 3: Learning Outcomes for ENGN 1410 at both campuses.

\begin{tabular}{|l|l|l|}
\hline \multicolumn{2}{|l|}{ Course Learning Objectives (LOs) } & $\begin{array}{l}\text { CEAB } \\
\text { Graduate } \\
\text { Attributes } \\
\text { (GAs) }\end{array}$ \\
\hline LO \# 1 & $\begin{array}{l}\text { Define what sustainability } \\
\text { means in engineering } \\
\text { design. }\end{array}$ & GA09, GA12 \\
\hline LO \# 2 & $\begin{array}{l}\text { Model and implement total } \\
\text { life materials cycles when } \\
\text { developing products and } \\
\text { processes. }\end{array}$ & GA01 to GA05 \\
\hline $\begin{array}{l}\text { Consider the social, } \\
\text { economic, environmental, } \\
\text { and cultural factors, and } \\
\text { their inter-relationships, } \\
\text { contributing to the general } \\
\text { understanding of } \\
\text { Sustainability. }\end{array}$ & $\begin{array}{l}\text { GA09, GA11, } \\
\text { GA12 }\end{array}$ \\
\hline LO \# 4 & $\begin{array}{l}\text { Work as a team to analyze } \\
\text { and communicate the } \\
\text { impact technological } \\
\text { innovation and engineering } \\
\text { design has on sustainability. }\end{array}$ & $\begin{array}{l}\text { GA06, GA07, } \\
\text { GA09 }\end{array}$ \\
\hline LO \# 5 & $\begin{array}{l}\text { Reflect on the individual's } \\
\text { impact as a global citizen } \\
\text { and sustainable design } \\
\text { engineering student. }\end{array}$ & GA08 to GA10, \\
GA12 \\
\hline
\end{tabular}


Table 4: Course Content for ENGN 1410: The Engineer as a Global Citizen

\begin{tabular}{|c|c|}
\hline \multicolumn{2}{|c|}{ Sustainability as a Global Citizen (Weeks 1-7) } \\
\hline Facets of Sustainability & Specific Topics \\
\hline Environment & $\begin{array}{l}\text { Nature, Wildlife, Oceans, } \\
\text { Greenhouse Gases }\end{array}$ \\
\hline $\begin{array}{l}\text { Charters, Guidelines \& } \\
\text { Theories }\end{array}$ & $\begin{array}{l}\text { UN Sustainability Charter } \\
\text { of Rights and Freedoms }\end{array}$ \\
\hline Waste and Urbanization & Plastics \\
\hline $\begin{array}{l}\text { Population and } \\
\text { Globalization }\end{array}$ & Water \\
\hline Lifestyle and Culture & $\begin{array}{l}\text { "Buying Local", Culture \& } \\
\text { Lifestyle, Supply Chain }\end{array}$ \\
\hline \multicolumn{2}{|c|}{ Sustainability as an Engineer (Weeks 8-14) } \\
\hline Energy and Electricity & Types, Forms, and Sources \\
\hline $\begin{array}{l}\text { Philosophy of } \\
\text { Technology }\end{array}$ & Accessibility and AI \\
\hline Ethics & Stakeholder Analysis \\
\hline $\begin{array}{l}\text { Sustainability and } \\
\text { Design }\end{array}$ & Materials Life Cycle \\
\hline $\begin{array}{l}\text { Sustainability: Current } \\
\text { News Analysis }\end{array}$ & $\begin{array}{l}\text { Biofuels } \\
\text { Advanced Manufacturing } \\
\text { Robotics } \\
\text { Biomimicry } \\
\text { Renewable Energy }\end{array}$ \\
\hline Leadership & $\begin{array}{l}\text { Sustainable Engineering } \\
\text { Design for Community and } \\
\text { Campus }\end{array}$ \\
\hline
\end{tabular}

\subsection{Team-Based Laboratory Projects}

There were three (3) team-based laboratory projects for ENGN1410.

\subsubsection{Upcycling of Rice Husk into} Sustainable Paper. In the first laboratory project, Cairo students were introduced to the environmental concerns associated with the uncontrolled burning of rice husk in Egypt. They were then asked to design paper products from risk husk to mitigate the environmental concern and provide a supplementary paper product for the local market. As shown in Figure 1 , students demonstrated creativity and innovation in the various types and quality of paper products produced, from gift wrap, to notebooks, to upcycled packaging containers. The project aimed to practice many of the course topics, such as waste management, design of a responsible product, and climate change mitigation. The project constraint was to be compliant as much as they can with the twelve green engineering principles such as "meet need, minimize excess", "maximize efficiency", "output pulled versus input pushed" and "conserve complexity" [9]. While the two instructors explored the use of wheat husk during the Cairo instructor's visit to UPEI, this paper-making project has not yet been implemented in the FSDE offering of the course.

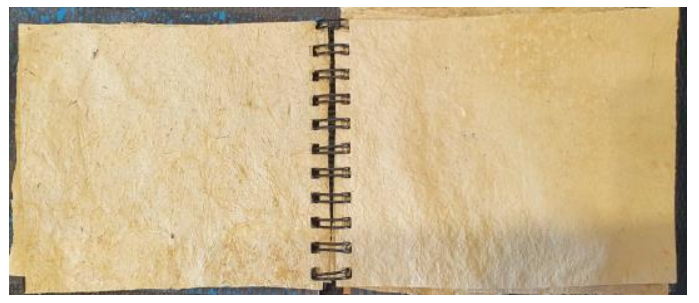

Fig. 1. Paper produced from rice husk.

2.3.2. Recycling of Used Cooking Oil into Sustainable Soap. In the second laboratory project, students were introduced to the fact that in Mediterranean countries, three to five kilograms of used cooking oil are generated per person per year [6]. Similarly, Canada generates 0.135 million tons of used cooking oil per year [5]. Used cooking oil eventually finds its way to the sewage system causing environmental, social, and economic problems. Students were then asked to research, design, and produce branded soap products from used cooking oil using saponification, as shown in Figure 2. In addition to mitigating the health hazard associated with improper disposal of household used cooking oil, the project also aimed to help students develop a sustainability mindset by producing a product that can provide local people with entrepreneurial, employment opportunities. Students in Cairo were asked to assess their soap's efficiency in dirt removal, discuss the difference between their laboratory-made soap and the commercial soap, and list the criteria that future engineers think are important to consumers when buying soap. FSDE students explored Design of Experiments concepts by measuring and comparing the volume of soap suds produced when laboratorymade soap and commercial soap (Ivory and Irish Spring) were subjected to a set number of agitations (to simulate washing) in $40^{\circ} \mathrm{C}$ water and cold water, using well water and water from the city water supply. Project constraint was to be compliant with the twelve green engineering principles during their design process, emphasizing the first principle, "Inherent rather than circumstantial," to ensure the safety of the soap product to the consumers [6][9]. 


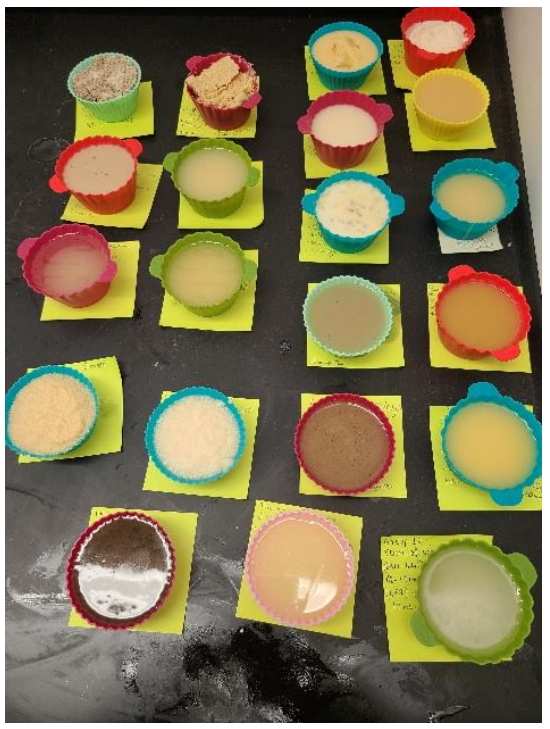

Fig. 2. Soaps made from recycled cooking oil (corn or a canola-blend) during the saponification process.

2.3.3. Assembly and Testing of DyeSensitized Solar Cells using Locally Produced Berries. In the third lab, students explored the use of local or native sources of anthocyanins (juice from berries) to make dye-sensitized organic photovoltaics, learning the introductory steps to semiconductor processing. Dye sensitized solar cells are "mini photovoltaics" which use a dye to absorb light and generate an electric current. The cells are composed of an anode and cathode, both of which are made with glass, which has an electrically conductive coating on one side. This coating on the cathode is a transparent conductive material such as indium-tin oxide (ITO) with a deposited layer of graphite. The anode's conductive side is coated with a layer of titanium dioxide that has been cured, which when deposited with a stain of anthocyanin, any light that is present is absorbed by the dye (anthocyanin). The semiconductive reaction is thus triggered, where electrons have enough energy to be activated to the semiconductor's conduction band and flow from the anode through an electrical load, such as a light bulb, multimeter or motor, to the cathode. An electrolyte transfers excess electron from the cathode back to the oxidized dye molecules where the cycle begins again. In this lab, students had the choice of blueberries, blackberries, strawberries, and raspberries grown locally to use as their sources of anthocyanin, and they could also use a frozen berry-mix and/or pomegranate juice purchased from the grocery store. Students tested their solar cells in at least three different intensities of light: sunlight (noting time of day), under a flashlight or smartphone light, and in room lighting. The raw data collected included voltage and current and the technical memo that was written focused on the analysis of Energy in these three conditions. While the two instructors practiced this lab during the Cairo instructor's visit to UPEI, this project has not yet been implemented in the Cairo offering of the course due to inability to source the necessary chemicals and coated glass slides.

\subsection{Leadership in Sustainability}

In addition to the team-based laboratory projects, there was a 3-week-long "Living Lab" team-based assignment conducted at both campuses that asked students to consider the impact of their individual consumption of plastics, quantify the classes' collective plastic waste, and evaluate the end-of-life options for the various types and categories of plastic. The details of this assignment were described in a previous CEEA-ACEG conference paper [4]. As well each campus developed team-based assignments focused on developing leadership in sustainability, as described in this section.

2.4.1. Exploring Sustainability Initiatives on Campus. This project encouraged FSDE students, in self-selected groups, to identify an issue on campus that could be addressed sustainably and improve UPEI operations, in relationship for example to the campus location, land, facilities, academics, external partnerships and research. Students prepared a report and presented a verbal briefing to invited staff and members of the administration to share their ideas and in some cases witnessed their recommendations put into action "on the spot" by the invited guest. The student presentations also provided key supporting evidence on how their initiative would improve sustainability and further create a culture of sustainability amongst faculty, staff, students and the community at large.

2.4.2. Innovative Sustainable Engineering Design Products for COVID-19. This project encouraged Cairo students, in self-selected groups, to review the current literature to identify and analyze a specific engineered project that has been developed to "alleviate either the impact or the spread of the coronavirus" pandemic. The project consisted of a report and a presentation, including an introduction of a compiled list of what the students believed to be innovative engineering designed products recently introduced to the market to alleviate the impact of COVID-19. Other details for the students to address included:

- A detailed description of how the product works, with photos and engineering drawings.

- A definition and scope of the innovation elements of the selected product.

- A discussion of the potential sustainability impacts of the innovative engineering designed product that had been selected. 
- A discussion of the impacts of the products' performance on the three sustainability pillars.

- A recommendation if any sustainability pillar was not tackled adequately in the product design

- A discussion for improvement to the design for the future and why this improvement might be useful.

\subsubsection{Evaluation of Corporate}

Sustainability Reports and Comparison of Sustainable Performance. This project encouraged Cairo student, in self-selected groups, to select sustainability reports for two different companies in the same industry and provide a summary and critical analysis of their sustainable performance. Students focused their comparison in relation to the United Nation's Sustainable Development Goals [10]. Students prepared a report and presentation in which they suggested recommendations for better sustainable performance to address the different pillars of sustainability for each of their selected companies.

\section{DISCUSSION}

An assessment of how well the main graduate attributes were achieved (i.e. GA9: Impact on Society and Environment; GA6: Individual and Team Work, and GA13: Lifelong Learning), as linked to the course's learning outcomes, in developing a sustainability mindset in UPEI FSDE undergraduate students is presented in the following sections. In addition, the instructors provide a reflection and recommendations for the course in the context of international collaboration going forward.

\subsection{Course Planning and Synergy}

The most important aspects of establishing an international branch campus and international collaboration for the simultaneous offering of a CEABaccredited program are (1) program planning and support from the leadership of the host institution and the international branch campus, (2) a commitment to delivery of the course content and objectives consistently, and (3) shared interest, commitment, expertise, and enthusiasm between the instructors and amongst the staff at both institutions to work together.

Although the instructors for ENGN 1410 discussed and decided that flexibility in the actual projects delivered would be appropriate, due to the availability of materials and supplies, as well as cultural norms, there was unswerving commitment to maintaining the shared and clear themes of sustainability, environmental stewardship, and the impact of engineering and engineering design on society. For example, the rice husk project is intrinsic to the history and culture of Egypt (from ancient papyrus to the fine quality and process of Egyptian paper today); similarly, the promotion of local, agricultural products (berries) is intrinsic to PEI culture.

\subsection{Assessment of Graduate Attributes}

Table 5 shows the grading rubric used to assess student performance on the two laboratory projects of the upcycling of rice husk (UofCanada-Cairo) and the recycling of used cooking oil (both campuses). The main graduate attributes (GA) assessed are GA4: design, GA5: Use of engineering tools, GA9: Impact on Society and Environment; GA6: Individual and Teamwork, and GA13: Lifelong Learning [1].

Table 5: Grading Rubric for Laboratory Projects

\begin{tabular}{|c|c|c|c|}
\hline $\begin{array}{l}\text { Unsatisfactory } \\
\text { (1) }\end{array}$ & $\begin{array}{l}\text { Developing } \\
(2)\end{array}$ & $\begin{array}{l}\text { Satisfactory } \\
(3)\end{array}$ & $\begin{array}{l}\text { Exemplary } \\
(4)\end{array}$ \\
\hline \multicolumn{4}{|c|}{ GA4 \& GA 5: Design and use of engineering tools } \\
\hline $\begin{array}{l}\text { Did not collect } \\
\text { information on } \\
\text { product design, } \\
\text { and did not use } \\
\text { any tools to } \\
\text { design their } \\
\text { products }\end{array}$ & $\begin{array}{l}\text { Collected } \\
\text { very little } \\
\text { information } \\
\text { on product } \\
\text { design, and } \\
\text { did not use } \\
\text { any tools to } \\
\text { design their } \\
\text { products }\end{array}$ & $\begin{array}{l}\text { Collected } \\
\text { some basic } \\
\text { information } \\
\text { on product } \\
\text { design and } \\
\text { used basic } \\
\text { engineering } \\
\text { tools to } \\
\text { design their } \\
\text { products } \\
\text { such as hand } \\
\text { sketches }\end{array}$ & $\begin{array}{l}\text { Collected a } \\
\text { great deal of } \\
\text { information } \\
\text { on product } \\
\text { design and } \\
\text { used } \\
\text { advanced } \\
\text { engineering } \\
\text { tools to } \\
\text { design their } \\
\text { products } \\
\text { such as } \\
\text { SolidWorks }\end{array}$ \\
\hline \multicolumn{4}{|c|}{ GA9: Impact of the product on society and environment } \\
\hline $\begin{array}{l}\text { Products have } \\
\text { a profound } \\
\text { detrimental } \\
\text { impact on } \\
\text { society and the } \\
\text { environment } \\
\text { such as misuse } \\
\text { of water or } \\
\text { energy } \\
\text { resources }\end{array}$ & $\begin{array}{l}\text { Products } \\
\text { have a } \\
\text { detrimental } \\
\text { impact on } \\
\text { society and } \\
\text { the } \\
\text { environmen } \\
\mathrm{t}\end{array}$ & $\begin{array}{l}\text { Products } \\
\text { partially } \\
\text { alleviate the } \\
\text { negative } \\
\text { social and } \\
\text { environment } \\
\text { al impact of } \\
\text { the available } \\
\text { alternative } \\
\text { products }\end{array}$ & $\begin{array}{l}\text { Products } \\
\text { fully } \\
\text { alleviate the } \\
\text { negative } \\
\text { social and } \\
\text { environment } \\
\text { al impact of } \\
\text { the available } \\
\text { alternative } \\
\text { products }\end{array}$ \\
\hline \multicolumn{4}{|c|}{ GA6: Work effectively in Teams } \\
\hline $\begin{array}{l}\text { Did not } \\
\text { perform any } \\
\text { duties or } \\
\text { contribute to } \\
\text { the assigned } \\
\text { team }\end{array}$ & $\begin{array}{l}\text { Performed } \\
\text { very little } \\
\text { duties and } \\
\text { often needs } \\
\text { reminding }\end{array}$ & $\begin{array}{l}\text { Performed } \\
\text { nearly all } \\
\text { assigned } \\
\text { duties and } \\
\text { rarely needs } \\
\text { reminding }\end{array}$ & $\begin{array}{l}\text { Performed } \\
\text { all the } \\
\text { assigned } \\
\text { duties and } \\
\text { showed } \\
\text { leadership }\end{array}$ \\
\hline \multicolumn{4}{|c|}{ GA13: Life-long Learning } \\
\hline $\begin{array}{l}\text { Unable to } \\
\text { address own } \\
\text { educational } \\
\text { need to } \\
\text { contribute to } \\
\text { the } \\
\text { advancement } \\
\text { of knowledge } \\
\text { in the future }\end{array}$ & $\begin{array}{l}\text { Achieved } \\
\text { little ability } \\
\text { to address } \\
\text { own } \\
\text { educational } \\
\text { need to } \\
\text { contribute } \\
\text { to the } \\
\text { advanceme } \\
\text { nt of future } \\
\text { knowledge }\end{array}$ & $\begin{array}{l}\text { Achieved } \\
\text { sufficient } \\
\text { ability to } \\
\text { address own } \\
\text { educational } \\
\text { need to } \\
\text { contribute to } \\
\text { the } \\
\text { advancement } \\
\text { of future } \\
\text { knowledge }\end{array}$ & $\begin{array}{l}\text { Achieve } \\
\text { superior } \\
\text { ability to } \\
\text { address own } \\
\text { educational } \\
\text { need to } \\
\text { contribute to } \\
\text { the } \\
\text { advancement } \\
\text { of future } \\
\text { knowledge }\end{array}$ \\
\hline
\end{tabular}


The assessment of the laboratory projects included both the evaluation of the technical memorandums and the quality of the final products submitted. The laboratory memos indicated that the students applied the concepts of sustainability. For example, for the rice husk project, some memos elaborate on the upcycling process as a preferred method for waste management compared with rice husk treatment and disposal. Additionally, students at the UofCanada-Cairo campus highlighted the positive impact of their products on mitigating climate change by reducing deforestation for primary paper production. As mentioned in 2.3.1., the students presented various responsible products, in addition to paper, such as paper bags and paper cups that were presented as alternatives to plastic packaging used in the local market. Figure 3 shows the assessment outcome of the rice husk project in Cairo according to the above-mentioned grading rubric, with most projects achieving an evaluation of "exemplary (4)" for the noted Gas

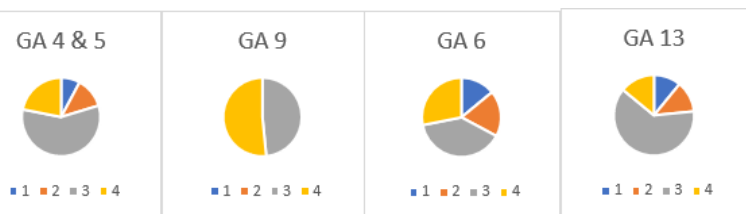

Fig. 3. Assessment outcome of the rice husk project in Cairo, with most projects achieving an evaluation of "exemplary" for the noted GAs.

Similarly, Figure 4 shows the assessment outcome of the sustainable soap project at both campuses according to the to the above-mentioned grading rubric, with most projects achieving an evaluation of "satisfactory (3)" and "exemplary (4)" for the specified GAs. The students highlighted the ability to boost the local economy through a low-cost production of soap products that are safer and cheaper than the soap available in the market. Students enjoyed this project and were inspired by how making sustainable soap could impact the community from a social perspective, e.g. the opportunity to source used cooking oil from dining halls and local diners was appealing to FSDE students.

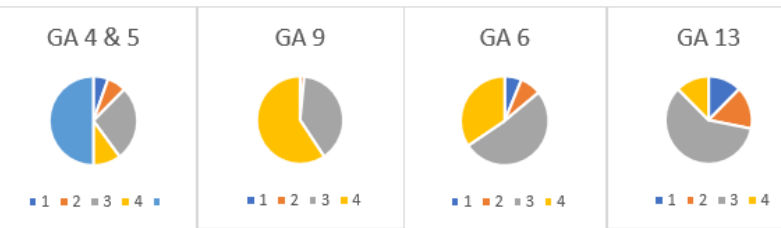

Fig. 4. Assessment outcome of the sustainable project project at both campuses, with most projects achieving an evaluation of "satisfactory" and "exemplary" for the noted GAs.

\subsection{Continuous Improvement}

The projects' assessment outcomes affirm that students at both campuses can work in teams to evaluate the impact of current engineering designs on society and environment and design more sustainable products in the future. Going forward, the concepts, issues, and frameworks pertaining to Sustainability in Engineering Design will continue to be introduced (I) and developed (D) as a first-year experience. Students developed their abilities to analyze and communicate on many aspects of sustainability; however, the focus of pedagogical improvement will be consistency in the development of technical skills and the application of technical abilities. For example, the UPEI campus introduced students to the quantification of energy savings (through calculations of personal energy usage), calculations and use of materials selection software for life cycle and end-of-life energy savings and greenhouse gas emissions comparisons, as well as what inputs and dependent variables are in experimental testing for engineering design. The ability to compare and analyze one's own data collected in the lab for validity, reliability, and repeatability are important skills to develop at the firstyear level of an undergraduate engineering program. In addition, the opportunity to interact with licensed professional engineers who engage with ENGN1410 students on how sustainability is a crucial component of their engineering work is important for both campuses. Going forward the focus of the international collaboration for this course will be to strengthen the analytical skills, technical abilities, and confidence of the students such that their understanding of sustainability is applied in their future engineering courses and projects and articulated through critical thinking, empathy and leadership. Sustainability as a global citizen and as an engineer means the integration of technical analysis with global, social, economic, environmental, cultural factors and understanding their inter-relationships.

\section{CONCLUSION}

In the course "ENGN 1410 Sustainability in Engineering Design", first-year engineering students at both the UPEI and UofCanada-Cairo campuses formulate an articulate definition of sustainability as they progress through the course, considering their integrated role as global citizens and future engineers. Students developed a critical understanding of Sustainability by participating in multiple in-person lab projects developing sustainable product designs such as sustainable paper products, soaps, and solar cells. They also participate in several team-based projects and assignments, focused on understanding the impact that they can make individually and collectively towards sustainability in engineering design. The collaboration between the two campuses focused on understanding the Human Development Index (HDI), the UN Sustainable Development Goals, and the theme of 
engineering's impact on society and their application to the experiential learning aspects of the course.

\section{References}

[1] Canadian Engineering Accreditation Board, 2017 Accreditation Criteria and Procedures, Engineers Canada, October 2017, 126 pp. \{ISSN: 1708-8054\}. Available as of November 29, $2020 \quad$ from https://engineerscanada.ca/sites/default/files/accr editation-criteria-procedures-2017.pdf

[2] 2C-BERT. 2021. About Us - C-BERT. [online] Available at: http://cbert.org/about-us/ [Accessed 8 January 2021].

[3] Girdzijauskaitè, E., Radzevičienè, A. \& Jakubavičius, A., 2019. Impact of international branch campus KPIs on the university competitiveness: FARE method. Insights into Regional Development, 1(2), pp.171-180. Available at: http://dx.doi.org/10.9770/ird.2019.1.2(7)

[4] Hsiao, A. 2019. Sustainability in Engineering Design. Proceedings of the 2019 Canadian Engineering Education Association Conference, June 8-12 Ottawa, ON. Available at: https://doi.org/10.24908/pceea.vi0.13877

[5] Math, M.C., Kumar, S.P. \& Chetty, S.V., 2010. Technologies for biodiesel production from used cooking oil - A review. Energy for Sustainable Development, 14(4), pp.339-345. Available at: http://dx.doi.org/10.1016/j.esd.2010.08.001

[6] Peiró, L. T., Méndez, G. V., \& Durany, X. G. i. (2008). Exergy Analysis of Integrated Waste Management in the Recovery and Recycling of Used Cooking Oils. Environmental Science \& Technology, 42(13), 4977-4981. Avaiable at: http://doi:10.1021/es071972

[7] Staniškis, J.K. \& Katiliūtè, E., 2016. Complex evaluation of sustainability in engineering education: case \& analysis. Journal of Cleaner Production, 120, pp.13-20. Available at: http://dx.doi.org/10.1016/j.jclepro.2015.09.086

[8] Wilkins, S. \& Huisman, J., 2012. The international branch campus as transnational strategy in higher education. Higher Education, 64(5), pp.627-645. Available at: http://dx.doi.org/10.1007/s10734-012-9516-5

[9] Zimmerman, J.B. and Anastas, P.T, Design through the Twelve Principles of Green Engineering, Env. Sci. and Tech., 37, 5, 94A101A, 2003. Available at: https://pubs.acs.org/doi/pdf/10.1021/es032373g

[10] United Nations Sustainable Development Goals, Available at: https://sdgs.un.org/goals 